\title{
Range extension of Neoporus superioris (Balfour-Browne, 1944) (Insecta: Coleoptera) into Wyoming, USA
}

\author{
J. Cody Bish ${ }^{1}$, Lusha M. Tronstad ${ }^{1 *}$ and Kelsey M. Brown ${ }^{2}$ \\ 1 University of Wyoming, Wyoming Natural Diversity Database. 82071, Laramie, WY USA. \\ 2 University of Wyoming, Ecosystem Science and Management. 82071, Laramie, WY USA. \\ * Corresponding author. E-mail: tronstad@uwyo.edu
}

\begin{abstract}
We report a new state record of Neoporus superioris (Balfour-Browne) from Crook County, Wyoming, USA. This new record represents the most southern extent of $N$. superioris known.
\end{abstract}

Aquatic beetles are a large and diverse group, with 12,600 described species worldwide (Jäch and Balke 2008). The predaceous diving beetles (family Dytiscidae) are the most specious family of aquatic beetles, with nearly 4,000 described species (Jäch and Balke 2008). The taxonomy for North American predaceous diving beetles is well studied (Larson et al. 2000) and the distribution of most species in the family are well known.

Within the family Dytiscidae, the genus Neoporus Guignot (subfamily Hydroporinae, tribe Hydroporini) includes 40 species of small to medium sized (2.2 to $6.4 \mathrm{~mm}$ ) light colored beetles that inhabit slow moving permanent water with submerged vegetation (Larson et al. 2000). The genus is distributed across the Nearctic region, with most species occupying the Appalachian area of eastern North America. Neoporus superioris (BalfourBrowne 1944) was originally described in 1850 from Lake Superior as Hydroporus sericeus (LeConte 1850; Larson 1975). Balfour-Browne (1944) later renamed the species as Hydroporus superioris, which is now accepted as a junior synonym for $N$. superioris (Hilsenhoff 1995). Neoporus superioris is the most northern distributed species of Neoporus and is found as far north as Northwest Territories, with its southern range limit extending into Montana, South Dakota, Minnesota, and Wisconsin (Larson et al. 2000; Figure 1.). The previous southernmost collection of $N$. superioris was in St. Croix County, Wisconsin (4458'2.5” N, 92³3'25.5” W; Wisconsin Insect Research Collection; Daniel Young, personal communication).

Ken Brown and Cody Bish collected specimens of N. superioris on 26 May 2011 in Prairie Creek where it intersects County Road 68 in Wyoming (44²3'32.6” N, 105¹'0.6" W; Little Missouri River Basin, Crook County; $1195 \mathrm{~m}$; Figure 1). This fourth order stream was $\sim 4 \mathrm{~m}$ wide and $\sim 1 \mathrm{~m}$ in depth and was flowing quickly due to high spring runoff. We dip-netted in the emergent vegetation among rushes in the slower moving water along the stream edge. Neoporus superioris was not previously known from Wyoming, and the new locale represents the most southern extent of the distribution of this species. Several other water beetle taxa were collected along with N. superioris: Berosus sp (Hydrophilidae)., Peltodytes callosus LeConte and Haliplus immaculicollis Harris (Haliplidae), in addition to four other Dystiscidae species (Agabus seriatus Say, Rhantus gutticollis Say, Laccophilus maculosus maculosus Say, Laccophilus maculosus decipiens LeConte). All these beetles were identified by Kelsey M. Brown following Larson et al. (2000). It is worth stressing that $N$. superioris is normally found in permanent lakes or slow flowing perennial streams with emergent vegetation such as rushes and sedges (Larson et al. 2000). Further, the benthic substrate was mainly composed of fine particles, which is typical of the habitat of $N$. superioris (Larson et al. 2000). The water chemistry analysis conducted at the sampling site revealed that the water had relatively high specific conductivity $(1440 \mu \mathrm{S} / \mathrm{cm})$ and $\mathrm{pH}$ was slightly

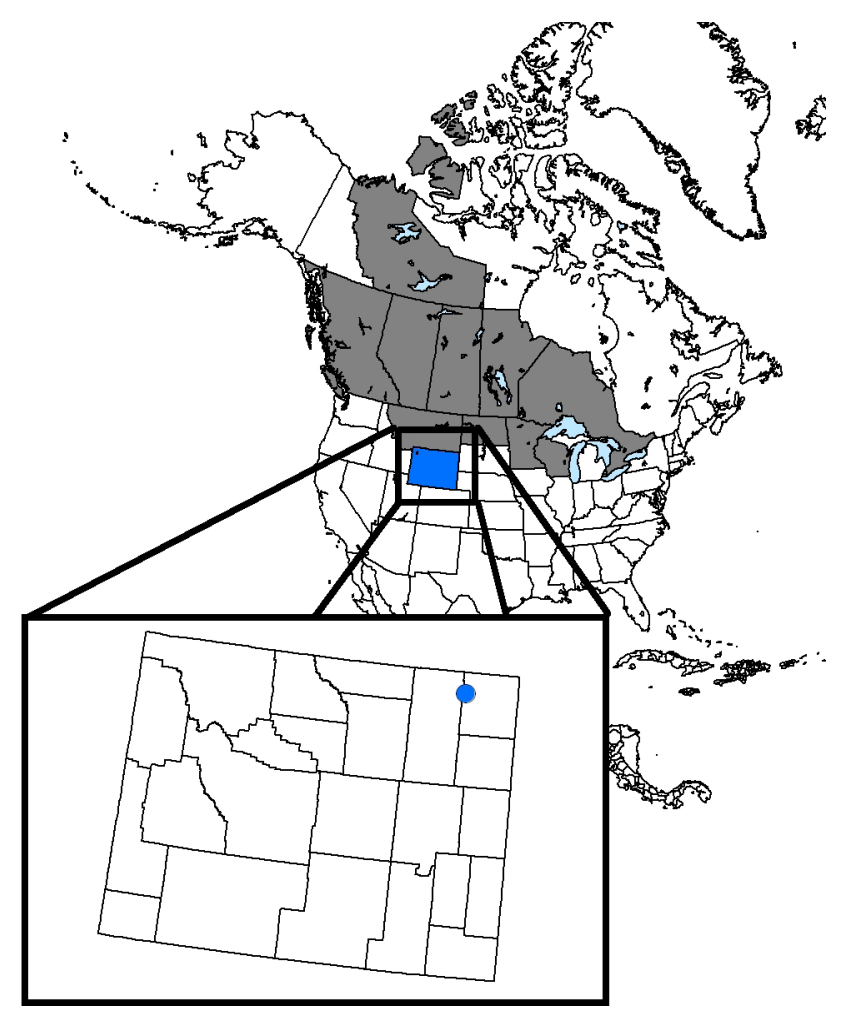

FigurE 1. Neoporus superioris is known from 10 states and provinces (grey), and we report a new state record for Wyoming (blue). The inset map shows the new locale in Wyoming (blue dot). 
alkaline (8.07). Voucher specimens of $N$. superioris collected for this study are housed in the Insect Museum at the University of Wyoming (Curator Dr. Scott Shaw).

ACKNOWLEDGMENTS: We thank Mark Anderson for help with creating the map. Michael Dillon and Mark Anderson provided helpful reviews. Wyoming Game and Fish Department provided funding. We are grateful to Daniel Young, University of Wisconsin-Madison, for specimen information in Wisconsin.

\section{Literature Cited}

Balfour-Browne J. 1944. New names and new synonymies in the Dytiscidae (Col.). The Annals and Magazine of Natural History. 11(78): 345-359.

Hilsenhoff, W.L. 1995. Dytiscidae and Noteridae of Wisconsin (Coleoptera). VI. Distribution, habitat, life cycle, and identification of species of Hydroporus Clairville sensu 1010 (Hydroporinae). The Great Lakes Entomologist. 28(1): 20
Jäch, M.A. and M. Balke. 2008. Global diversity of water beetles (Coleoptera) in freshwater. Hydrobiologia. 595(1): 419-442.

Larson, D.J. 1975. Predaceous water beetles of Alberta: Systematics, natural history, and distribution. Quaestiones Entomologicae. 11: 288-289.

Larson, D.J., Y. Alarie, and R.E. Roughley, 2000. Predaceous Diving Beetles (Coleoptera:Dystiscidae) of the Neartic Region, with emphasis on the fauna of Canada and Alaska. Ottawa, National Research Council of Canada.

LeConte, J.L. 1850. General remarks upon the Coleoptera of Lake Superior. Agassiz, "Lake Superior", p.201-208

RECEIVED: December 2012

ACCEPTED: April 2013

Published ONLINE: June 2013

EDITORIAL RESPONSIBILITY: Ricardo Ribeiro de Castro Solar 